\title{
Assessment of Serum Minerals in Subclinical Hypothyroid and Overt Hypothyroid Patients
}

Ram K. Jat ${ }^{1}$, Anil K. Panwar ${ }^{1}$, Pradeep Agarwal ${ }^{1}$, Chandrashekhar Sharma ${ }^{2}$, Dharam P. Bansal ${ }^{1}$, Arpit Pareek $^{1}$, Ambika Tyagi ${ }^{1}$, Monali Mathur ${ }^{1}$

1. General Medicine, Mahatma Gandhi Medical College and Hospital, Jaipur, IND 2. General Medicine, Sawai Man Singh Medical College and Hospital, Jaipur, IND

Corresponding author: Ram K. Jat, drramkishanjat01@gmail.com

\section{Abstract}

\section{Background}

Hypothyroidism, the commonest form of hormonal dysfunction, is due to thyroid hormone deficiency or its impaired activity. Homeostasis of the metabolism of minerals is regulated by thyroid hormones. If there is any disorder of the thyroid it will lead to disturbances of metabolism of minerals.

\section{Aim}

To study and compare serum calcium and serum phosphorus levels in patients of subclinical hypothyroidism and correlation of these parameters with thyroid-stimulating hormone (TSH) levels.

\section{Materials and methods}

This study included 70 patients with subclinical hypothyroidism, 70 patients with overt hypothyroidism, and 70 age- and sex-matched healthy controls. Thyroid profile (estimation of free triiodothyronine [FT3], free thyroxine [FT4], TSH) was done. In both cases and controls serum calcium and serum phosphorus levels were estimated.

\section{Results}

Serum calcium and phosphorus levels in patients of subclinical hypothyroidism was $8.75 \pm 0.40 \mathrm{mg} / \mathrm{dL}$ and $3.80 \pm 0.62 \mathrm{mg} / \mathrm{dL}$, respectively. In patients with hypothyroidism it was $8.37 \pm 0.52 \mathrm{mg} / \mathrm{dL}$ and $4.10 \pm 0.75$ $\mathrm{mg} / \mathrm{dL}$, respectively, and in controls it was $9.67 \pm 0.97 \mathrm{mg} / \mathrm{dL}$ and $3.70 \pm 0.71 \mathrm{mg} / \mathrm{dL}$, respectively. Difference between these groups was statistically significant $(\mathrm{p}<0.05)$. Mean serum calcium and phosphorus for patients with TSH level $<10$ was $8.81 \pm 0.33 \mathrm{mg} / \mathrm{dL}$ and $3.67 \pm 0.60 \mathrm{mg} / \mathrm{dL}$, respectively, and for TSH level $>10$ was $8.59 \pm 0.51 \mathrm{mg} / \mathrm{dL}$ and $4.12 \pm 0.54 \mathrm{mg} / \mathrm{dL}$, respectively. The difference between both groups was statistically significant $(\mathrm{p}<0.05)$ for calcium, phosphorus .

Review began 07/06/2021 Review ended 07/19/2021 Published 08/06/2021

\section{(c) Copyright 2021}

Jat et al. This is an open access article distributed under the terms of the Creative Commons Attribution License CC-BY 4.0., which permits unrestricted use, distribution, and reproduction in any medium, provided the original author and source are credited.

\section{Conclusions}

In subclinical hypothyroidism serum calcium and serum phosphorus levels are significantly altered. Regular follow-up and estimating serum levels of these minerals in subclinical hypothyroidism patients should be done so it is beneficial to give mineral supplementations to prevent bone complications during the treatment of the disease.

Categories: Internal Medicine

Keywords: calcium, phosphorus, subclinical hypothyroidism, thyroid stimulating hormone, thyroid hormones

\section{Introduction}

Hypothyroidism is one of the most common endocrine disorders worldwide [1]. The prevalence of hypothyroid is $10-11 \%$ in India [2]. Hypothyroidism is caused by decreased levels of thyroid hormones and it is among the most common endocrine disorders. Subnormal activity of the thyroid gland in hypothyroidism leads to mental and physical slowing because of a decrease in the basal metabolic rate [3]. The prevalence of spontaneous hypothyroidism is between $1 \%$ and $2 \%$ and is more common in older women and 10 times more common in women than in men [4].

Subclinical hypothyroidism, defined as an elevated serum thyroid-stimulating hormones (TSH) level with normal levels of free thyroxine (FT4) affects up to 10\% of the adult population [5]. Subclinical (without obvious symptoms) hypothyroidism (low thyroid function) describes a situation in which thyroid function is only mildly low, so that the blood level of thyroxine remains within the normal range but the blood level of TSH is elevated [6]. Subclinical hypothyroidism, which is defined as elevated thyroid-stimulating hormone (TSH) levels with free thyroxine concentrations within the reference range, is a common disorder that 


\section{Cureus}

increases with age and affects up to $18 \%$ of the elderly, with a higher prevalence in women compared to men [7].

Thyroid hormones have a vital role in the growth and of the skeletal system and its maturation. TSH is a ligand hormone between the hypothalamic-pituitary axis and the thyroid gland. TSH has long been recognized to act on the thyroid gland to control follicle development and thyroid hormone production and secretion. Beyond the thyroid, TSH has also been shown to have additional effects on other tissues. TSH can exert a direct effect on bone metabolism independently of the peripheral thyroid hormone (thyroxine [T4] and triiodothyronine [T3]) levels [8]. The role of thyroid hormones in phosphorus and calcium balance in the body by direct action on bone turnover have variously been reported in the literature. Phosphorus and ionized calcium metabolism are frequently altered in thyroid disease. A negative calcium balance may ultimately result in hyperthyroid osteopenia [9]. Calcium and phosphorus are important parts of the metabolic pathways regulated by the thyroid hormones [10].

Our aim in this study is to assess serum calcium and serum phosphorus levels in newly diagnosed hypothyroidism, subclinical hypothyroidism, and euthyroidism and compare them.

\section{Materials And Methods}

A hospital-based observational study was conducted in the Department of Medicine, Mahatma Gandhi Medical College Hospital, Jaipur, in 2018-19. Total 210 subjects included in this study were divided into three groups - euthyroid, subclinical hypothyroid, and hypothyroid. Seventy subjects included in each group were selected according to the inclusion and exclusion criteria and serum calcium, phosphorus levels were measured. Subjects aged 18-70 years were included in this study. Patients with a history of preexisting hepatic disease, renal disease, bone diseases, and other major medical conditions, patients with a history of alcohol abuse, diabetes mellitus, pediatric age group and persons on mineral supplementation or any medications that might affect serum calcium, magnesium, and phosphorous concentration were excluded from this study. In statistical methods, the p-value is obtained by applying a one-way analysis of variance (ANOVA).

\section{Results}

Mean FT3, FT4, and TSH in patients of subclinical hypothyroidism was $2.83 \pm 0.44 \mathrm{pg} / \mathrm{mL}, 1.22 \pm 0.36 \mathrm{ng} / \mathrm{dL}$, and $9.41 \pm 4.10 \mu \mathrm{IU} / \mathrm{mL}$, respectively. In patients with hypothyroidism it was $1.48 \pm 0.41 \mathrm{pg} / \mathrm{mL}, 0.49 \pm 0.14$ $\mathrm{ng} / \mathrm{dL}$, and $24.29 \pm 20.69 \mu \mathrm{IU} / \mathrm{mL}$, respectively, And in controls it was $2.94 \pm 0.48 \mathrm{pg} / \mathrm{mL}, 1.26 \pm 0.45 \mathrm{ng} / \mathrm{dL}$, and $2.12 \pm 1.20 \mu \mathrm{IU} / \mathrm{mL}$, respectively. Difference in FT3, FT4, and TSH was statistically significant $(\mathrm{p}<0.001)$ in all three groups. Serum calcium and phosphorus levels in patients of subclinical hypothyroidism was 8.75 $\pm 0.40 \mathrm{mg} / \mathrm{dL}$ and $3.80 \pm 0.62 \mathrm{mg} / \mathrm{dL}$, respectively. In patients with hypothyroidism they were $8.37 \pm 0.52$ $\mathrm{mg} / \mathrm{dL}$ and $4.10 \pm 0.75 \mathrm{mg} / \mathrm{dL}$, respectively, and in controls it was $9.67 \pm 0.97 \mathrm{mg} / \mathrm{dL}$ and $3.70 \pm 0.71 \mathrm{mg} / \mathrm{dL}$, respectively. Difference between these groups was statistically significant ( $<<0.05$ ) (Table 1, Figure 1).

\begin{tabular}{|c|c|c|c|c|}
\hline Parameters & Control & Subclinical Hypothyroidism & Hypothyroidism & p-value ${ }^{\star}$ \\
\hline FT3 (pg/mL) & $2.94 \pm 0.48$ & $2.83 \pm 0.44$ & $1.48 \pm 0.41$ & $<0.001$ \\
\hline FT4 (ng/dL) & $1.26 \pm 0.45$ & $1.22 \pm 0.36$ & $0.49 \pm 0.14$ & $<0.001$ \\
\hline TSH ( $\mu \mathrm{lU} / \mathrm{mL})$ & $2.12 \pm 1.20$ & $9.41 \pm 4.10$ & $24.29 \pm 20.69$ & $<0.001$ \\
\hline S. Calcium (mg/dl) & $9.67 \pm 0.97$ & $8.75 \pm 0.40$ & $8.37 \pm 0.52$ & $<0.001$ \\
\hline Phosphorus (mg/dl) & $3.70 \pm 0.71$ & $3.80 \pm 0.62$ & $4.10 \pm 0.75$ & 0.002 \\
\hline
\end{tabular}

TABLE 1: Comparison of Age, T3, T4, TSH, Serum Calcium, and Phosphorous Controls and Cases

* $p$-value as obtained on applying one-way analysis of variance

T3: triiodothyronine; T4: thyroxine; TSH: thyroid-stimulating hormone 


\section{Cureus}

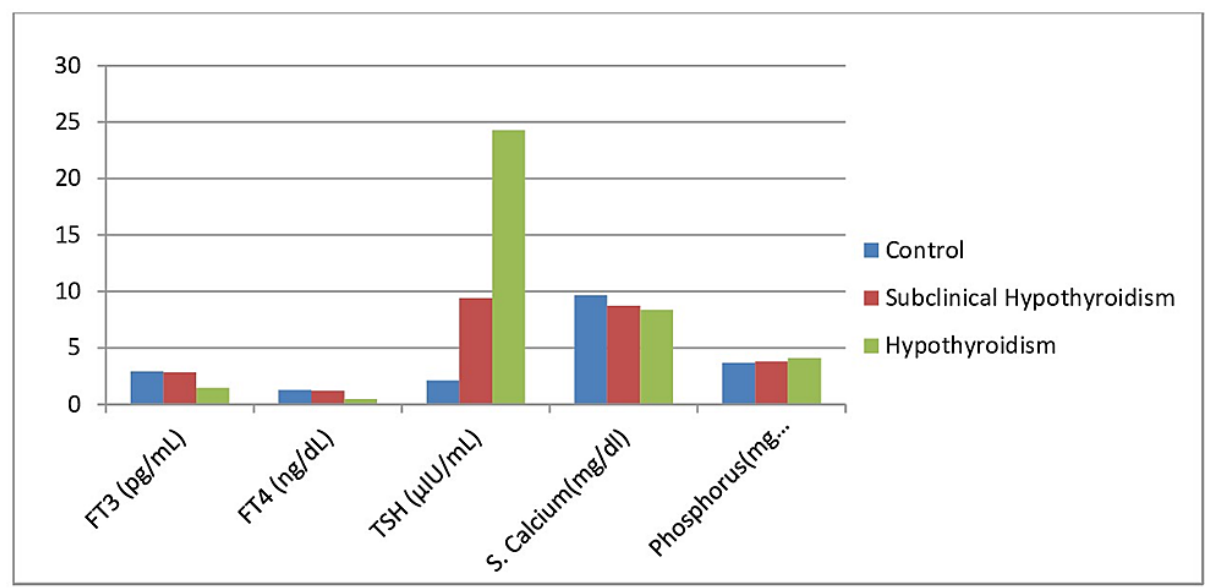

FIGURE 1: Comparison of FT3, FT4, TSH, Serum Calcium and Phosphorous in Cases and Controls

FT3: free triiodothyronine; FT4: free thyroxine; TSH: thyroid-stimulating hormone

In this study out of 70 cases of subclinical hypothyroidism 50 cases had TSH level $<10$ while 20 cases had TSH level $>10$ and the mean for these patients was $7.38 \pm 1.35 \mu \mathrm{IU} / \mathrm{mL}$ and $14.49 \pm 4.28 \mu \mathrm{IU} / \mathrm{mL}$, respectively (Table 2, Figure 2).

\begin{tabular}{|c|c|c|c|}
\hline Parameter & TSH $<10$ (50 cases) & TSH >10 (20 cases) & p-value \\
\hline FT3 (pg/mL) & $2.85 \pm 0.42$ & $2.85 \pm 0.42$ & 0.669 \\
\hline FT4 (ng/dL) & $1.20 \pm 0.34$ & $1.28 \pm 0.40$ & 0.401 \\
\hline Calcium (mg/dL) & $8.81 \pm 0.33$ & $8.59 \pm 0.51$ & 0.036 \\
\hline Phosphorus (mg/dL) & $3.67 \pm 0.60$ & $4.12 \pm 0.54$ & 0.005 \\
\hline
\end{tabular}

TABLE 2: Comparison of FT4 Levels in Sub-Clinical Hypothyroid Group Divided on the Basis of TSH Levels

FT3: free triiodothyronine; FT4: free thyroxine; TSH: thyroid-stimulating hormone 


\section{Cureus}

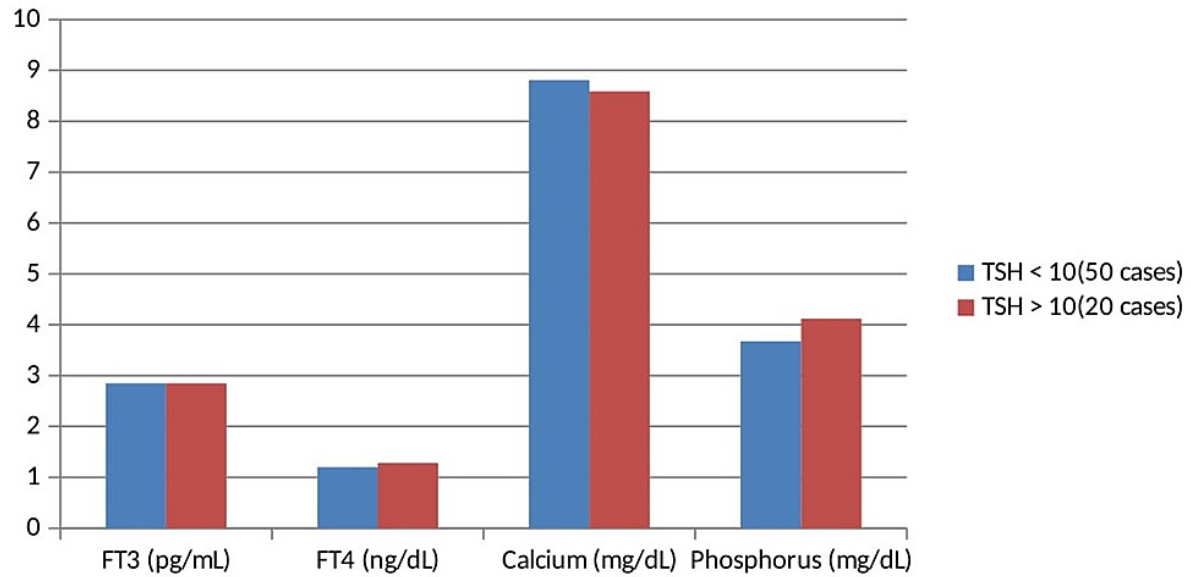

FIGURE 2: Comparison of FT4 Levels in Sub-Clinical Hypothyroid Group Divided on the Basis of TSH Levels

FT3: free triiodothyronine; FT4: free thyroxine; TSH: thyroid-stimulating hormone

Mean FT3 and FT4 for patients with TSH level $<10$ was $2.85 \pm 0.42 \mathrm{pg} / \mathrm{mL}$ and $1.20 \pm 0.34 \mathrm{ng} / \mathrm{mL}$, respectively, and for TSH level $>10$ it was $2.80 \pm 0.49 \mathrm{pg} / \mathrm{mL}$ and $1.28 \pm 0.40 \mathrm{ng} / \mathrm{mL}$, respectively. This difference was statistically non-significant $(\mathrm{p}>0.05)$.

Mean serum calcium and phosphorus for patients with TSH level $<10$ was $8.81 \pm 0.33 \mathrm{mg} / \mathrm{dL}$ and $3.67 \pm 0.60$ $\mathrm{mg} / \mathrm{dL}$, respectively and for TSH level $>10$ it was $8.59 \pm 0.51 \mathrm{mg} / \mathrm{dL}, 4.12 \pm 0.54 \mathrm{mg} / \mathrm{dL}$, respectively. Both groups had statistically significant difference $(\mathrm{p}<0.05)$.

In this study, serum calcium had a significant negative correlation and serum phosphorus levels had a significant positive correlation with TSH levels ( $\mathrm{p}<0.05)$ (Table 3).

\begin{tabular}{|l|l|l|}
\hline Parameters & Correlation coefficient $(\mathbf{r})$ & $\mathbf{p}$-value \\
\hline TSH vs S. Calcium & -0.243 & 0.003 \\
\hline TSH vs S. Phosphorus & 0.317 & $<0.0001$ \\
\hline
\end{tabular}

TABLE 3: Correlation of Serum Calcium, Phosphorous with TSH Among Cases

TSH: thyroid-stimulating hormone

\section{Discussion}

The mean age in our study in patients with subclinical hypothyroidism was $40.4 \pm 13.33$ years, in patients with hypothyroidism was $41.07 \pm 10.78$ years, and in controls was $37.30 \pm 13.19$. It shows age-matched cases and controls $(\mathrm{p}=0.165)$.

In this study, we found mean serum calcium levels in patients of subclinical hypothyroidism, hypothyroidism, and in controls was $8.75 \pm 0.40 \mathrm{mg} / \mathrm{dL}, 8.37 \pm 0.52 \mathrm{mg} / \mathrm{dL}$ and $9.67 \pm 0.97 \mathrm{mg} / \mathrm{dL}$ respectively. These results show significantly $(\mathrm{p}<0.001)$ low values of serum calcium in patients of subclinical hypothyroidism and overt hypothyroidism in comparison to euthyroid patients.

Our results correlate with a study conducted by Kavitha MM et al [11], Arvind Bharti et al [12] - they found the mean serum calcium levels were significantly $(\mathrm{p}<0.001)$ low in subclinical hypothyroidism patients and overt hypothyroidism patients in comparison to euthyroid patients. According to Zahra $\mathrm{N}$ et al study, the Level of calcium and phosphorus were determined in patients with hypothyroidism. The level of calcium decreased in female hypothyroid patients $(3.1263 \pm 0.56122)$ as compared to control $(8.7714 \pm$ $0.23604)$ but the level of phosphorus $(8.3316 \pm 0.35037)$ in female patients with hypothyroidism was increased than the control $(3.3143 \pm 0.49473)$. The same trends were observed in the males when calcium and phosphorus levels were determined in hypothyroidism patients. Results were statistically significant at $\mathrm{p}<0.01$ [13]. Long-term hyperthyroidism resulted in net negative calcium ion (Ca2+) balance in response to 
increased skeletal turnover. It is noteworthy here that a long-term hyperthyroid state is also associated with malabsorption of $\mathrm{Ca} 2+$ and increased bone resorption. On the other hand, hyperthyroidism is known to increase renal blood flow, glomerular filtration rate (GFR) and reabsorption of inorganic phosphate (Pi), $\mathrm{Ca} 2+$, and sodium ion $(\mathrm{Na}+)[14]$.

In our study, we found mean serum phosphorus level in patients of subclinical hypothyroidism, hypothyroidism, and in controls was $3.80 \pm 0.62 \mathrm{mg} / \mathrm{dL}, 4.10 \pm 0.75 \mathrm{mg} / \mathrm{dL}$, and $3.70 \pm 0.71 \mathrm{mg} / \mathrm{dL}$, respectively. These results show significantly $(\mathrm{p}<0.001)$ high values of serum phosphorus levels in patients of subclinical hypothyroidism and overt hypothyroidism in comparison to euthyroid patients. Our results correlate with the study conducted by Kavitha MM et al [11] and Arvind Bharti et al [12] - they found the mean serum phosphorus levels were significantly $(\mathrm{p}<0.001)$ high in subclinical hypothyroidism patients and overt hypothyroidism patients in comparison to euthyroid patients. The mechanisms of thyroid hormoneinduced bone resorption include cyclic adenosine monophosphate (cAMP)-mediated, increased sensitivity of beta-adrenergic receptors to catecholamines, increased sensitivity of bone cells to parathyroid hormone (PTH), osteoclast activator factor, and interleukin-1 (IL-1)-mediated increased bone resorption. Previous studies revealed that hypocalcemia is seen in hypothyroidism this is mainly due to the low levels of PTH and low levels of calcitriol [15].

We divided the patients of subclinical hypothyroidism into two subgroups according to the level of TSH. We found 50 cases of TSH level $<10$ and while 20 cases of TSH level $>10$ and mean TSH levels for these patients was $7.38 \pm 1.35 \mu \mathrm{IU} / \mathrm{mL}$ and $14.49 \pm 4.28 \mu \mathrm{IU} / \mathrm{mL}$, respectively.

In this study, we found that mean serum calcium for patients with TSH level $<10$ was $8.81 \pm 0.33 \mathrm{mg} / \mathrm{dL}$ and for TSH level $>10$ was $8.59 \pm 0.51 \mathrm{mg} / \mathrm{dL}$. This shows significantly low levels of calcium in patients with TSH levels of $>10(\mathrm{p}<0.05)$. We also found in this study significant ( $\mathrm{p}$-value $=0.003)$ negative correlation $(\mathrm{r}=\mathrm{-}$ 0.243 ) between TSH levels and serum calcium levels. It shows as TSH levels increase, serum calcium levels decreases. Our results correlate with the study conducted by Kavitha MM et al [11 ] which found a significant $(\mathrm{p}<0.001)$ negative correlation between calcium and TSH levels. A contrast study conducted by Bharti et al [12] in 2015 showed a negative but nonsignificant $(\mathrm{p}=0.45$ ) correlation between calcium and TSH levels.

In this study, we found that mean serum phosphorus for patients with TSH level $<10$ was $3.67 \pm 0.60 \mathrm{mg} / \mathrm{dL}$ and for TSH level $>10$ it was $4.12 \pm 0.54 \mathrm{mg} / \mathrm{dL}$. This shows significantly high levels of phosphorus in patients with TSH levels of $>10(p<0.05)$. We also found in this study a significant $(\mathrm{p}=<0.001)$ positive correlation $(\mathrm{r}=0.317)$ between TSH levels and serum phosphorus levels. It shows as TSH levels increase, serum phosphorus levels increases. Our results correlate with the study conducted by Kavitha MM et al [11] and Murgod et al [16] - they found a significant $(\mathrm{p}<0.05)$ positive correlation between phosphorus and TSH levels. Another study conducted by Bharti et al [12] in 2015 showed a positive but nonsignificant $(\mathrm{p}=0.45)$ correlation between phosphorus and TSH levels. Another contrast study conducted by Gammage MD et al [17] in 1986 showed a negative correlation of phosphorus with TSH.

\section{Conclusions}

To conclude, the present study gives us an idea that the derangement in level serum calcium and phosphorus is associated with skeletal deformities so it needs to be studied further. Considering all this we suggest that patients with hypothyroidism and subclinical hypothyroidism should be regularly checked for serum calcium and phosphorus. Early detection and treatment can prevent further complications and will be helpful during the management of thyroid patients.

\section{Additional Information \\ Disclosures}

Human subjects: Consent was obtained or waived by all participants in this study. Mahatma Ghandhi Medical College and Hospital issued approval MGMCH/IEC/JPR/2018/05. Approval of the institutional ethics committee for conducting the study entitled "An Association of Serum Calcium, Serum Magnesium, Serum Phosphorus and Serum Thyroglobulin with Hypothyroidism, Subclinical Hypothyroidism, Euthyroidism; Hospital based observational study". Animal subjects: All authors have confirmed that this study did not involve animal subjects or tissue. Conflicts of interest: In compliance with the ICMJE uniform disclosure form, all authors declare the following: Payment/services info: All authors have declared that no financial support was received from any organization for the submitted work. Financial relationships: All authors have declared that they have no financial relationships at present or within the previous three years with any organizations that might have an interest in the submitted work. Other relationships: All authors have declared that there are no other relationships or activities that could appear to have influenced the submitted work.

\section{References}

1. Unnikrishnan AG, Menon UV: Thyroid disorders in India: an epidemiological perspective. Indian J Endocrinol Metab. 2011, 15 :S78-81. 10.4103/2230-8210.83329

2. Unnikrishnan AG, Kalra S, Sahay RK, Bantwal G, John M, Tewari N: Prevalence of hypothyroidism in adults: 
an epidemiological study in eight cities of India. Indian J Endocrinol Metab. 2013, 17:647-52. 10.4103/22308210.113755

3. Ashmaik AS, Gabra HM, Elzein AOM, Shrif NEMA, Hassan EE: Assessment of serum levels of calcium and phosphorous in Sudanese patients with hypothyroidism. Asian J Biomed Pharma Sci. 2013, 2:21-6.

4. Vanderpump MP, Tunbridge WM: Epidemiology and prevention of clinical and subclinical hypothyroidism . Thyroid. 2002, 12:839-47. 10.1089/105072502761016458

5. Biondi B, Cappola AR, Cooper DS: Subclinical hypothyroidism: a review. JAMA. 2019, 322:153-60. 10.1001/jama.2019.9052

6. Pluta RM, Burke AE, Glass RM: JAMA patient page. Subclinical hypothyroidism. JAMA. 2010, 304:1402. 10.1001/jama.304.12.1402

7. Baumgartner C, Blum MR, Rodondi N: Subclinical hypothyroidism: summary of evidence in 2014. Swiss Med Wkly. 2014, 144:w14058. 10.4414/smw.2014.14058

8. Eva Feigerlova, Marc Klein, Anna Angelousi, Lelia Groza and Georges Weryha: Thyroid disorders and bone mineral homeostasis. Thyroid Hormone. Agrawal NK (ed): IntechOpen, 2012.

9. Mendez D, Kunder M, Shashidhar KN, Venkataswam L: A comparative study of the ionic and total calcium levels in women with thyroid dysfunction. Int J Med Sci Pub Health. 2016, 5:633-7. 10.5455/ijmsph.2016.1208201599

10. Susanna TY, Sagayaraj A, Shashidhar KN, Gomathi M, Mahesh V: A correlative study of thyroid profile and mineral status in patients with hypothyroidism - a hospital based case control study. Asian J Pharm Clin Res. 2016, 9:292-4.

11. Kavitha MM, Chandrashekharyya SH, Kashinakunti SV, Sunitha H, Neela BM, Ratna S: Alteration in levels of serum calcium, phosphorous and magnesium in patients of hypothyroidism. Int J Biol Med Res. 2014, 5:4594-6.

12. Bharti A, Shrestha A, Rai R, Singh MK: Assessment of serum minerals and electrolytes in thyroid patients . Int J Adv Sci Res. 2015, 1:259-63.

13. Zahra N, Ali A, Kousar S, Malik A, Zaheer A, Malik IR: Study on significant changes in calcium, phosphorus and thyroid hormones level in hypothyroidism patients. Adv Life Sci. 2020, 8:85-8.

14. Kumar V, Prasad R: Molecular basis of renal handling of calcium in response to thyroid hormone status of rat. Biochim Biophys Acta. 2002, 1586:331-43. 10.1016/s0925-4439(01)00111-9

15. Suneel B, Nagendra DR, Aparna RR, Balakrishna D, Naidu JN: Mineral status in thyroid disorder (hypo \& hyper). Int J Appl Biol Pharma Tech. 2011, 2:423-429.

16. Murgod R, Soans G: Changes in electrolyte and lipid profile in hypothyroidism . Int J Life Sci Pharma Res. 2012, 2:185-94.

17. Gammage MD, Logan SD: Effects of thyroid dysfunction on serum calcium in the rat . Clin Sci (Lond). 1986, 71:271-6. 10.1042/cs0710271 